\title{
Gravity anomaly to identify Walanae fault using second vertical derivative method
}

\author{
Marsellei Justia $^{1}$, Muhammad Fikri H Hiola ${ }^{1}$, Nur Baiti Febryana $\mathrm{S}^{\mathbf{1}}$ \\ ${ }^{1}$, State Collage of Meteorology, Climatology and Geophysics \\ J1. Perhubungan 1 no. 5, Pondok Betung, Pondok Aren, Tangerang Selatan, Kode Pos 15221 \\ Email: justiamarsell@gmail.com
}

Received 21 February 2018, Revised 24 March 2018, Published 31 March 2018

\begin{abstract}
Research has been conducted to identify the Walanae Fault, coordinates 4-6 S and 118-120 E using anomalous gravity data. This research uses data measurement of Topography and the Free Air Anomaly from the TOPEX/Poseidon satellite. Then the authors processed to obtain the bouguer anomalies and made modeling by using the Surfer 10. The authors used the Second Vertical Derivative (SVD) with filter Elkins of Moving Average then analyze the graph of the SVD. The results shows the value of the residual anomaly in the north of fault is $25.21 \mathrm{mGal}$, in the middle occur range $17.67 \mathrm{mGal}$ to $24.98 \mathrm{mGal}$ and $30,376 \mathrm{mGal}$ in the south of fault. The authors indicates the existence of a difference between the gravity between the Walanae Fault with surrounding geologic. From these results also show that Walanae Fault has a reverse fault mechanism in the northern part and the normal fault mechanism in the middle to the south, the authors conclude that the Walanae Fault is divided into two segments, that is the northern and the southern segment.
\end{abstract}

Keywords: Gravity, SVD, Anomaly

\section{Introduction}

Sulawesi is one of the regions in Indonesia with a relatively high seismic level because of its location which is an active collision of three plates (triple junction): the Indian-Australian Plate which moves relative to the north, the Eurasian Plate which is relatively silent and the Pacific Plate in the east. One of Indonesia's regions with high earthquake and tsunami vulnerability is Sulawesi. Sulawesi and the surrounding area have geological structures, especially regional faults. The main geological structures of Sulawesi include the Palu-Koro Fault, Walanae Fault, Matano Fault, Batui Fault, Poso thrust Fault, Balantak Fault, Gorontalo Fault, North Sulawesi allowance, and Bone Bay. These active faults are often the cause of earthquakes in the Sulawesi region based on seismic data, especially those in the Southern Sulawesi region (Surono and Hartono, 2015).

Sulawesi and its surrounding areas have a tectonic order pattern that is composed of local geological structures. The geological structure is the Walanae Fault (South Sulawesi Arm), Lawanopo Fault (Sulawesi Southeast Arm), Matano Fault (Central Sulawesi), Palu-Koro Fault (Central Sulawesi), Batui Fault (Maluku Sea and Tomini 
Bay) and Double Subduction Maluku Sea (Sangihe Talaud Islands and Maluku Sea) (Ismullah et al., 2014).

Rab Sukamto (1982), argues that tectonic activities in the Early Miocene period led to the start of Walanae lying extending from north to south in the Western Sulawesi arm. The fault structure affects the surrounding geological structure. This tectonic causes a basin to form the Walanae Formation. This event most likely took place from the beginning of the Middle Miocene and declined slowly during sedimentation until the Pliocene period. The decline of Walanae was limited to two normal fault systems, namely the Walanae Fault which was all visible to the present in the east and Soppeng Fault which was only exposed continuously to the west.

This Walanae Fault is one of the causes of earthquakes or seismic activity in the South Sulawesi region. This fault is shallow crustal type with shallow depth so that it has the effect of medium to strong shocks. On the other side, the Walanae Fault is close to the capital city of the province of South Sulawesi, which is Makassar with a population level and high building density so the level of threat and vulnerability is quite large.

Gravity method is one of the geophysical survey methods used to determine the geological/subsurface structure based on variations in the earth's gravitational field on the surface due to differences in lateral density. One application of the gravity method is to map the geological structure of faults such as estimating the location and type of fault. One tectonic threat is the people who live in the South Sulawesi region which is close to the Walanae Fault. For mitigation requirements due to earthquake, it is necessary to do research on the location of this type of Walanae Fault. In this study, the authors used the Simple Bouguer Anomaly (SBA) formula, which is Free Air Anomaly (FAA) and topographic data based on satellite imagery from TOPEX. Data from the TOPEX satellite has been corrected with drift correction, tide correction and latitude correction. Then the next analysis uses the second vertical or Second Vertical Derivative (SVD) derivative method developed by Elkins (1951) to estimate the location and type of fault of the study area.

\section{Methodology}

\subsection{Geological Conditions}

This tectonic model states that the Makassar Strait is interpreted as a foreland basin on both sides of the Sunda Land and the Australia-New Guinea Plate (Surono and Hartono, 2015). The geology of the eastern and western regions of South Sulawesi is basically different, where the two regions are separated by the Walanae Fault (Sompoton, 2012)

The fold-thrust fault lane of Kalosi are found in large granite plutons, ophiolite complex (Lamasi complex), and Latimojong pre tertiary bedrock (Surono and Hartono, 2015). In the Majene-Mamuju area to Palopo, it can be divided into three main tectonic domes which stretch north-south. The three dominance starts from the active thrust fault fold, volo-plutonic lane, and lane of polyolite rocks (Surono and Hartono, 2015). 
The presence of major faults such as the Walanae Fault also provides a role in the formation of small faults around it. This condition makes Sulawesi Island become an active tectonic region with a high level of seismicity (Massinai et al., 2013). Data and results of analysis of geological structures, such as the pattern of alignment and the direction of relative movement of faults, indicate that the deformation in the southern part of Sulawesi is affected by the activities of the Walanae fault (Sompoton, 2012). Sulawesi's geological map is shown in figure 1.

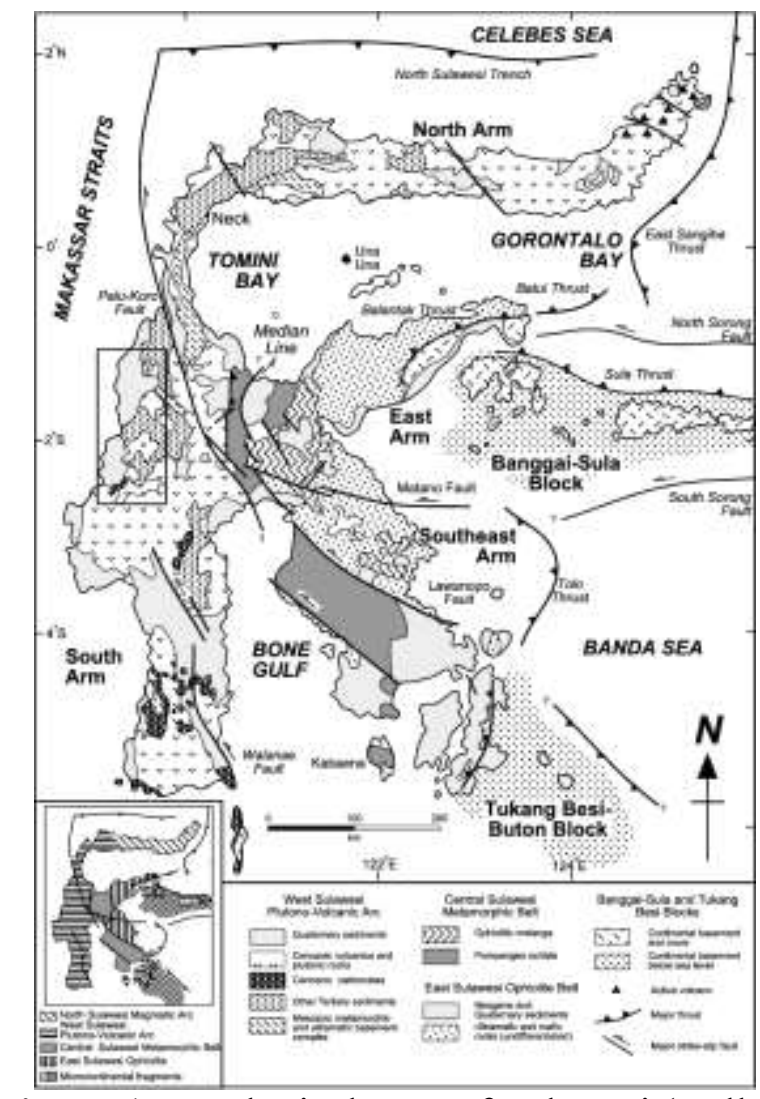

Figure 1. Geological Map of Sulawesi (Hall \& Wilson, 2000)

\subsection{Data}

The author's research area focuses on the area of South Sulawesi and the Walanae Fault with coordinates 40-60 S and 1180-1200 E. The data used is in the form of gravity values in the FAA (Free Air Anomaly) and topography of TOPEX. The data then processed to produce a bouguer anomaly which is input data to produce a Second Vertical Derivative (SVD) cross section and graphic.

\subsection{Gravity Anomaly}

The gravity anomaly is the difference values of the actual earth gravity (gravity observed in the field) with the value of the theoretical homogeneous gravity model in a particular reference datum.

$\delta g_{B}=2 \pi G \rho h$ 


$$
g_{B}=g_{F}-\delta g_{B}
$$

Previously, the authors determined the density value at the research location using the Parasnis (1952) which Parasnis's method is based on the fact that the bouguer anomaly can be expressed as an equation of the form of " $y=m x+b$ " (Mankhemthong et al. 2012).

$$
g_{o b s}-g_{N}+0.3086 h=(0.04193 h-T C) \rho+B A
$$

\subsection{Moving Average}

Moving average method used to get a residual value or superficial anomaly. Moving averages are obtained by subtracting measurement data (bouguer anomalies) and regional anomalies.

Mathematically the moving average value for one dimension expressed in the equation:

$$
\Delta g_{r}(i)=\frac{\Delta g(i-n)+\cdots+\Delta g(i)+\cdots+\Delta g(i+n)}{N}
$$

Whereas for two dimensions averaging values $\Delta g_{B}$ with a center point $\Delta g_{R}$.

\subsection{Second Vertical Derivative}

The SVD method aims to rise the superficial effects of the residual anomalies so anomalies can be obtained whereas represent the walanae fault lane. In this study the author used the Elkins operator (1951).

Table 1. SVD filter operators according to Elkins (1951)

\begin{tabular}{lllll}
\hline 0.0000 & -0.0833 & 0.0000 & -0.0833 & 0.0000 \\
\hline-0.0833 & -0.0667 & -0.0334 & -0.0667 & -0.0833 \\
\hline 0.0000 & -0.0334 & +1.0668 & -0.0334 & 0.0000 \\
\hline-0.0833 & -0.0667 & -0.0334 & -0.0667 & -0.0833 \\
\hline 0.0000 & -0.0833 & 0.0000 & -0.0833 & 0.0000 \\
\hline
\end{tabular}

Determination of the type of fault structure using the formulation of Reynolds (1997)

Normal fault, $\left|\frac{\partial^{2}(\Delta g)}{\partial z^{2}}\right| \min <\left|\frac{\partial^{2}(\Delta g)}{\partial z^{2}}\right| \max$

and thrust fault, $\left|\frac{\partial^{2}(\Delta g)}{\partial z^{2}}\right| \min >\left|\frac{\partial^{2}(\Delta g)}{\partial z^{2}}\right| \max$

\section{Result and Discussion}

Data processing of the results obtained by gravity bouguer anomaly map in Figure 2 which shows that the value of the anomaly in the area of research at coordinates 40-5.50 $\mathrm{S}$ and 119.50-1200 E tends to be different from the surrounding geology. In this 
research to see the difference in bouguer anomaly at Walanae Fault the authors divide the cross section into three parts that are clearly visible and significant difference, namely, section 1 , in this section it looks that there are anomalies of about $100 \mathrm{mGal}$ with the highest center $140 \mathrm{mGal}$, section 2, can be seen the difference significant anomalies around $100 \mathrm{mGal}$ with center reached $190 \mathrm{mGal}$ and in section 3, bouguer anomalies are quite low compared to the surrounding area that is only $40 \mathrm{mGal}$ and the smaller the on its center reaches $-10 \mathrm{mGal}$. These results are then processed with SVD method so that it gets the map of SVD as in Figure 3.On the SVD maps can be seen that there is the difference value of bouguer anomalies are smaller than the value of the bouguer anomaly in Figure 3.

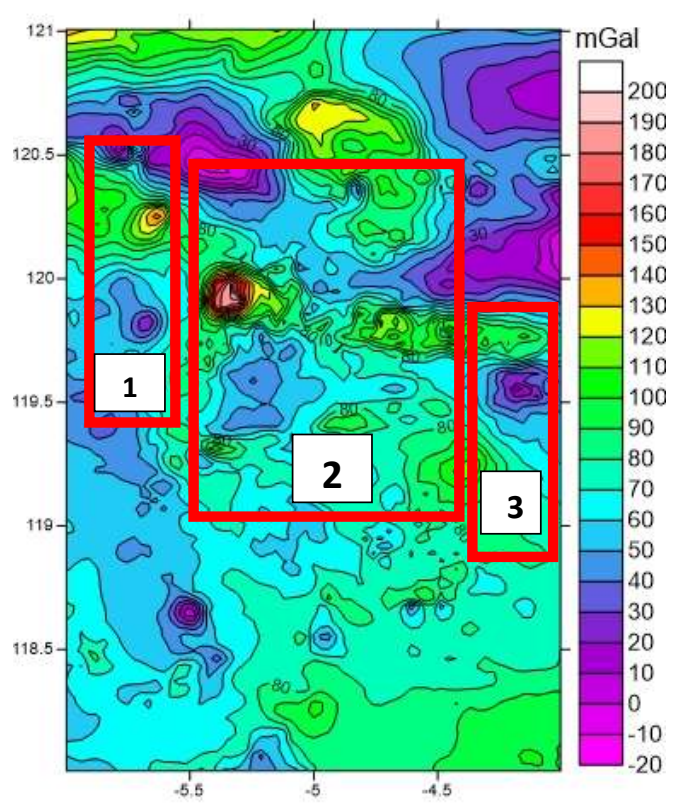

Figure 2. Bouguer Anomaly Map 


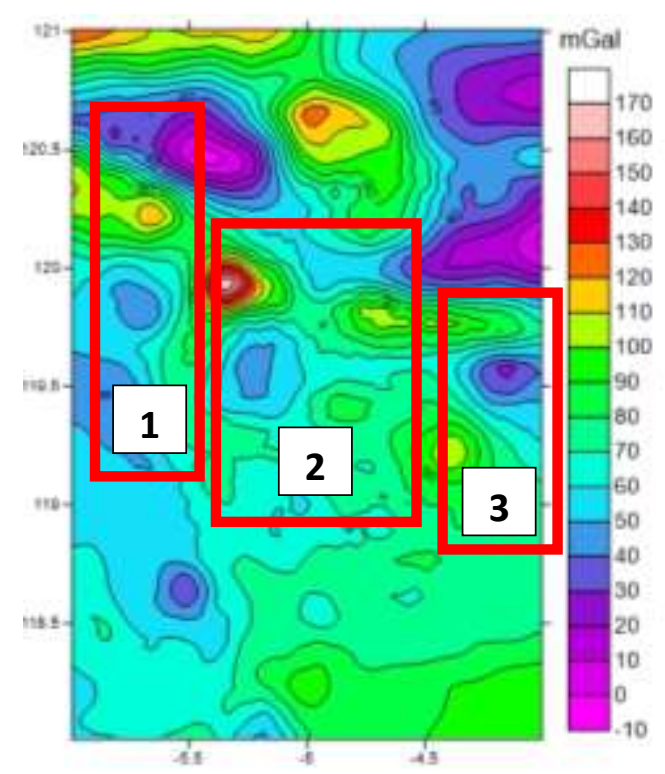

Figure 3. Second Vertical Derivative Map

The value of different anomaly around $80-110 \mathrm{mGal}$ in the first section, the 80-170 $\mathrm{mGal}$ in the second section and $20-40 \mathrm{mGal}$ in the third section. These results show the difference clearly fixed bouguer anomalies such as Figure 1 but with smaller values of the bouguer anomalies on the map in Figure 2.

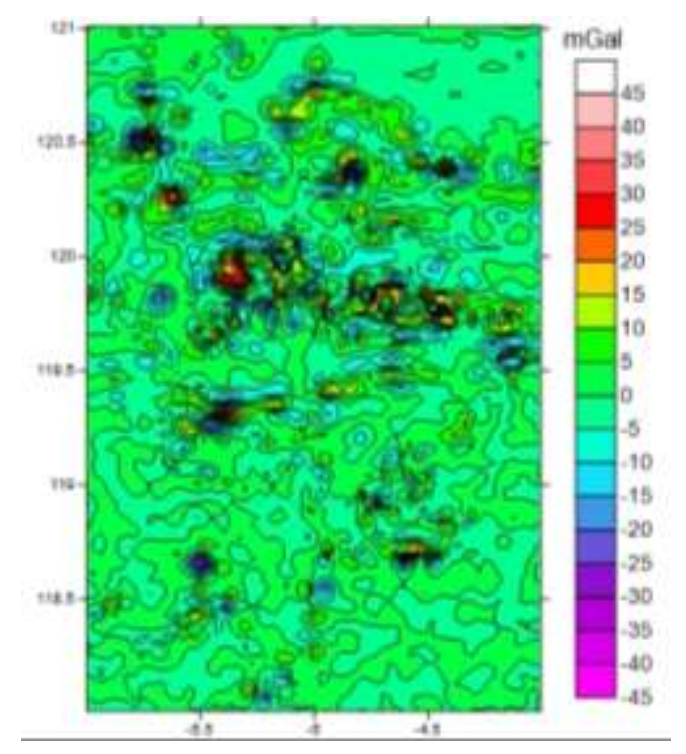

Figure 4. Residual Anomaly Map

From Figure 4 it can be seen a clearer difference on the Walanae Fault with area surrounding Walanae Fault. Anomalies are generated on this residual anomaly map with anomalies range between $-20-30 \mathrm{mGal}$. It can be seen in Figure 5, the authors made 7 slicing in these results for creating graphs of the SVD. 


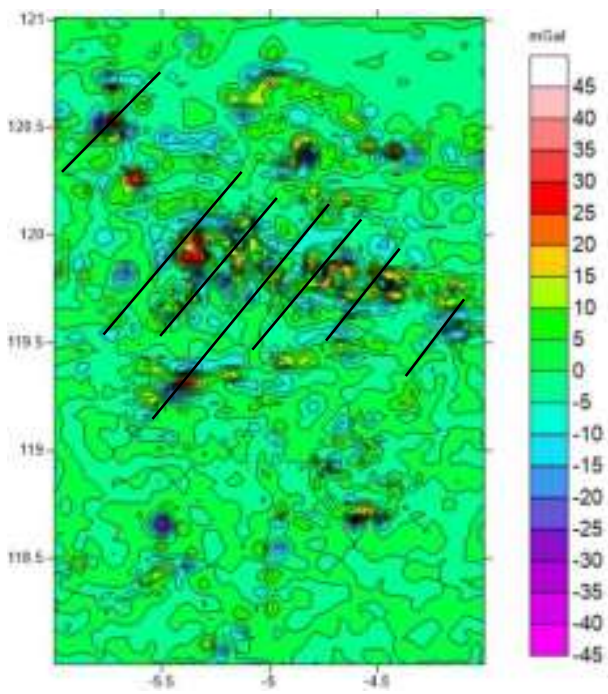

Figure 5. Slicing on Residual Anomaly Map

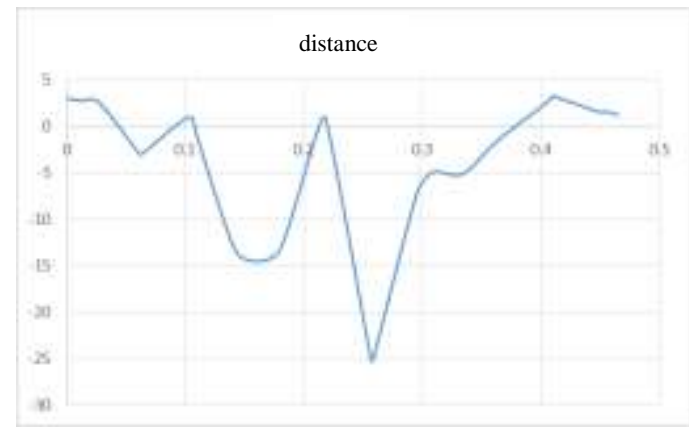

a

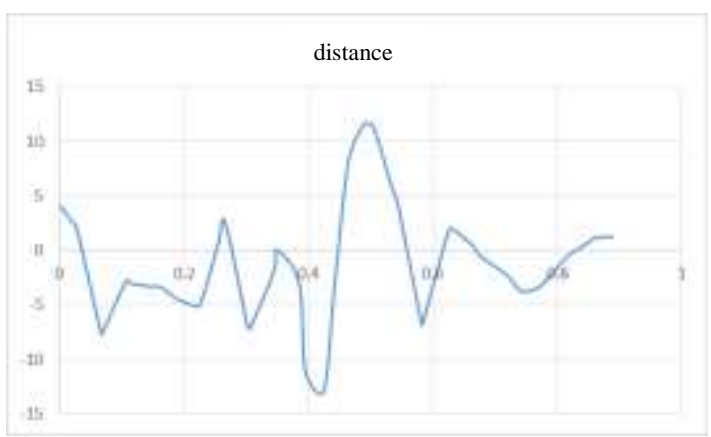

c

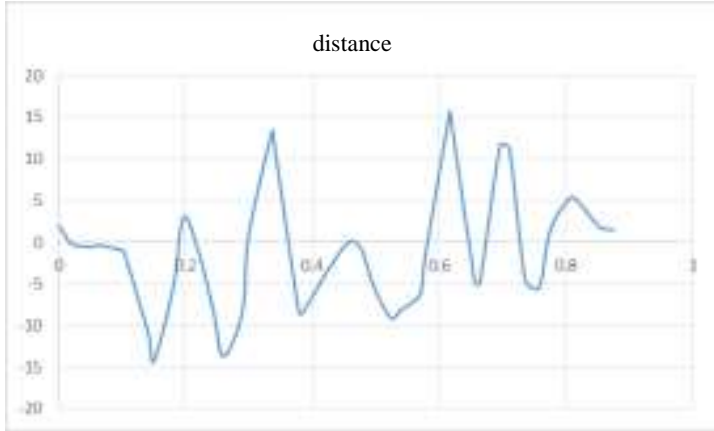

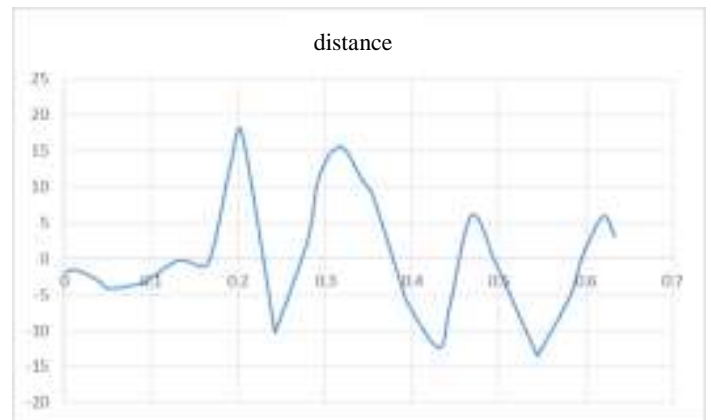

b

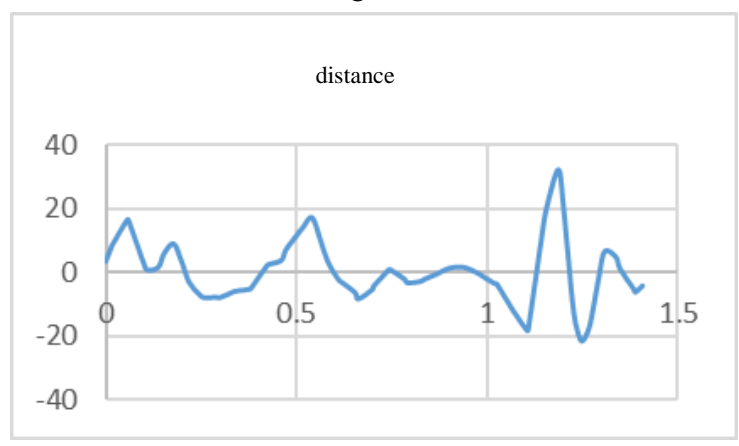

d

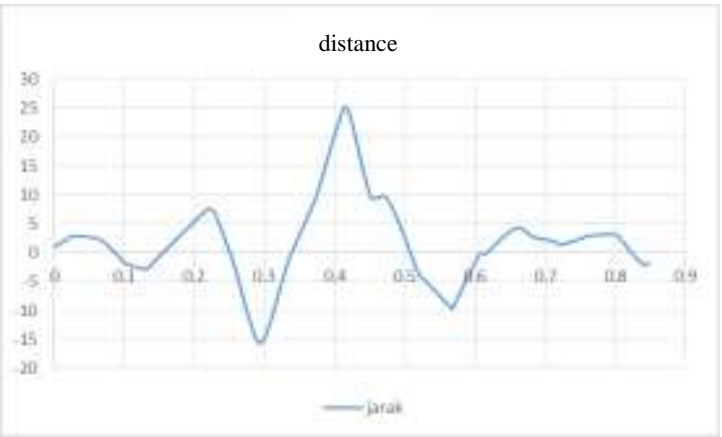


e

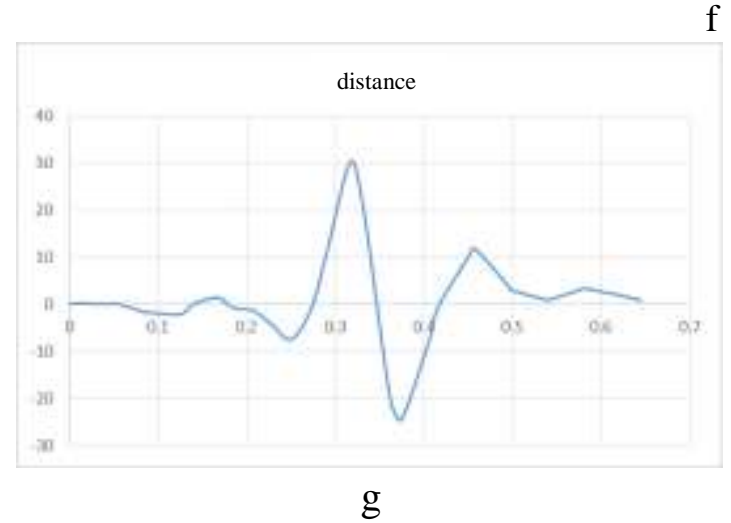

Figure 6. Second Vertical Derivative (SVD) graph (a, b, c, d, e, f, g)

For figure caption is like the example below. From Figure 6 can be seen on the graph the biggest anomaly is located on the minimum area in distance $0,259 \mathrm{~km}$ with maximum value about $-24,852 \mathrm{mGal}$. Graph b-g has the biggest anomaly is located on positive areas i.e. to graph $b$ at the distance $0,204 \mathrm{~km}$ with maximum value about $17,673 \mathrm{mGal}$, graph $\mathrm{c}$ at the distance $0,504 \mathrm{~km}$ with anomalous values about 11,332 $\mathrm{mGal}$, graph $\mathrm{d}$ at the distance $1,188 \mathrm{~km}$ with maximum value about $32,477 \mathrm{mGal}$, graph e at the distance $0,617 \mathrm{~km}$ with maximum value of $15,570 \mathrm{mGal}$, graph $\mathrm{f}$ at the distance $0,422 \mathrm{~km}$ with maximum value about $23,681 \mathrm{mGal}$ and graph $\mathrm{g}$ at the distance 0,318 $\mathrm{km}$ with maximum value about $30,317 \mathrm{mGal}$.

The value of the SVD graph showed that the average value of the anomalies is about $15,171 \mathrm{mGal}$ with maximum value about $32,477 \mathrm{mGal}$ and minimum about $-24,852$ $\mathrm{mGal}$. And there is a significant views in the picture is graph a with the maximum negative area shows the trend direction of the fault (Reynolds, 1979) while, in Figure b$\mathrm{g}$ graph shows the maximum value in the positive area are shows as the trend the direction of the fault is down. This is the underlying writer contended that the existence of two segments on the Walanae Fault, first is a fault with direction that has a tendency to ride on the north and the second is the fault with direction tends to fall on the middle area to south of fault (Reynolds, 1997).

\section{Acknowledgement}

We are very grateful to TOPEX/Poseidon satellite that had provided all the required topography and the free air anomaly data we used in this research.

\section{References}

Ismullah, Muhammad Fawzy., Lantu., Aswad, Sabrianto., Massinai, Muhammad Altin. (2014). Tectonics Earthquake Distribution Pattern Analysis Based Focal Mechanisms (Case Study Sulawesi Island, 1993-2012). Proceeding of American Institute of Physics, Bandung.

Mankhemthong N, Doser DI, Baker MR. (2012). Practical Estimation of Near-surface Bulk Density Variations Across the Border Ranges Fault System, Central Kenai Peninsula, Alaska. J Environ Eng Geophys. 17(3):51-158. doi: 10.2113/JEEG17.3.151. 
Massinai, Muhammad Altin., Sudrajat, Adjat., Lantu. (2013). The Influence of Seismic Activity in South Sulawesi Area to the Geomorphology of Jeneberang Watershed. Journal of Engineering and Technology, Vol 3, No.10, 945-948.

Elkins Thomas A. (1951). The Second Derivative Method Of Gravity Interpretation. Gulf Research \& Development Company, Pittsburgh, Pannsylvania, Vol. 16: Issue. 1, 29-50. Doi.org/10.1190/1.1437468

Parasnis DS. (1951). A study of rock densities in English Midlands. Geophys J Int. 6:252-271. doi: 10.1111/j.1365-246X.1952.tb03013.x.

Reynolds, J. M. (1997). An Introduction to Applied and Environmental Geophysics. John Wiley and Sons Inc. England.

S Hall, R. \& Wilson, M. E. J. (2000). Neogene sutures in eastern Indonesia. Journal of Asian Earth Sciences. 18, 781-808.

Sukamto, R., dan Supriatna, S. (1982). Geologi Lembar Pangkajene dan Watampone Bagian Barat Sulawesi. Pusat Penelitian dan Pengembangan Geologi Direktorat Jenderal Pertambangan Umum Depatemen Pertambangan dan Energi. Bandung. Indonesia.

Surono dan Hartono, Udi. (2015). Geologi Sulawesi. LIPI Press. Jakarta.

Sompotan, Armstrong F. (2012). Struktur Geologi Sulawesi. Perpustakaan Sains Kebumian Institut Teknologi Bandung. Bandung. 